\title{
ASSESSMENT OF PERFORMANCE AND LIVELIHOOD GENERATED THROUGH COMMUNITY BASED GOAT PRODUCTION IN BANGLADESH
}

\author{
M. O. Faruque ${ }^{* 1}$, M. P. Choudhury ${ }^{2}$, C. H. Ritchil ${ }^{3}$, F. Tabassum ${ }^{4}$ \\ M. A. Hashem ${ }^{5}$ and A. K. F. H. Bhuiyan ${ }^{6}$ \\ ${ }^{1}$ Sheep Development Project, Bangladesh Livestock Research Institute, Savar, Dhaka-1341 \\ ${ }^{2}$ Sheep and Goat Division, Bangladesh Livestock Research Institute, Savar, Dhaka-1341 \\ ${ }^{3}$ Department of Animal Breeding and Genetics, Bangladesh Agricultural University, \\ Mymensingh-2202 \\ ${ }^{4}$ Fodder Development Project, Bangladesh Livestock Research Institute, Savar, Dhaka-1341 \\ ${ }^{5}$ Department of Animal Science, Bangladesh Agricultural University, Mymensingh-2202 \\ ${ }^{6}$ Department of Animal Breeding and Genetics, Bangladesh Agricultural University, \\ Mymensingh-2202
}

\begin{abstract}
The study was undertaken to investigate the performance of Black Bengal goats and livelihood generated through goat rearing at 3 different villages namely Kaichapur, Salia and Shimulia at Phulpur Upazila (GPS: $24.9500^{\circ} \mathrm{N}$ and $90.3500^{\circ} \mathrm{E}$ ) of Mymensingh district in Bangladesh. The average birth weight, body weight at 6 and 12 months of Black Bengal goat (BBG) were $1.03 \pm 0.01 \mathrm{~kg}, 7.75 \pm 0.09$ and $12.77 \pm 0.16 \mathrm{~kg}$, respectively and daily body weight gain at 0-6 and 6-12 months of age were $34.38 \pm 0.54$ and $24.62 \pm 0.57 \mathrm{~g}$ respectively. The average litter size of does was $1.51 \pm 0.05$ and kid mortality rate was $12.58 \%$. The study revealed that, most of the goat owners were housewives. The educational status and goat rearing system of the farmers were also observed. Most of the farmers were either Primary (55\%) or illiterate $(38.3 \%)$. About $3.33 \%$ were below Secondary School certificate and $1.67 \%$ Higher Secondary School certificate level. Few farmers have completed their graduation (1.67\%). The average net profit from one goat in a year was Tk.754. The expenditure on food purchase, health care, education, clothing, housing condition and social status of the farmers were increased, respectively at a scale of $22.79 \%, 6.56 \%$, $14.47 \%, 4.34 \%, 14.22 \%$ and $19.35 \%$ due to increase of their income from goat rearing.
\end{abstract}

Keywords: Goat, livelihood, mortality, performance, weight gain

\footnotetext{
*Corresponding author email: omarbau07@gmail.com
}

Received: 17.11.2016 


\section{INTRODUCTION}

Goats are one of very important livestock species because of their short generation intervals and higher prolificacy. The technical assistance can be provided to the goat producers by organizing the rural goat keepers through community based goat production system. The local folks could be encouraged to establish their new herds with introduction of superior male germplasm, using modern techniques to regularize the production, improvement of performance of flocks and marketing of animals. The current study was undertaken to assess the contribution of income generated through Black Bengal goats rearing in changing household income and to the scale of livelihood changes at the rural community level.

\section{MATERIALS AND METHODS}

Data of the study was collected during November, 2011 to November, 2012 from the on-going UNEP-GEF-ILRI-FAnGR Asia research project through cooperative village started from October 2009 under the technical supervision of Department of Animal Breeding and Genetics, Bangladesh Agricultural University (BAU), Mymensingh and Area Development Project(ADP), World Vision Bangladesh, Phulpur, Mymensingh. All the society members were trained on scientific approaches of goat production, breeding, feeding, housing, disease control, record keeping and other management practices. Two hundred Black Bengal does were collected from different villages of Mymensingh district on the basis of their phenotypic character i.e., body size, and record of having at least two kids in each kidding. Four Black Bengal bucks were collected from the Bangladesh Livestock Research Institute (BLRI), Savar, Dhaka. These four bucks were given to four farmers who had previous experience on maintaining breeding buck. Forty goat rearing landless women farmers with previous experience of goat rearing were selected to form the Community Based Organization (CBO). Later 20 more goat rearing landless women farmers were joined to the $\mathrm{CBO}$. Initially four does were randomly distributed to each of the $40 \mathrm{CBO}$ members and later on two does were randomly distributed to each of $20 \mathrm{CBO}$ members. The birth weight, live weight, average daily weight gain, litter size, and kid mortality of 200 male and female goats at different periods and socio-economic variables were recorded during the study. The data generated from this experiment were entered in Microsoft Excel Worksheet, organized and processed for further analysis. Mean and standard errors (SE) for different traits were estimated with the help of Statistical Package for Social Science (SPSS) v.14.0 (2005). In addition, for significant independent variables, means were compared using Duncan's Multiple Range Test (DMRT). 


\section{RESULTS AND DISCUSSION}

\section{Performance of goats}

\section{Birth weight}

Average birth weights of male and female kids were $1.08 \pm 0.01$ and $0.98 \pm 0.01$ $\mathrm{kg}$ respectively with average of $1.03 \pm 0.01 \mathrm{~kg}$ (Table 1). Average birth weight of Black Bengal kids were 1.03 and $0.93 \mathrm{~kg}$ for male and female in Bangladesh (Husain, 1993) which is similar with the present findings. Husain et al. (1996) reported that weight at birth varied significantly $(\mathrm{p}<0.01)$ according to sex in Black Bengal goats, the male kids have higher birth weight $(1.06 \pm 0.02 \mathrm{~kg})$ than females $(0.93 \pm 0.02 \mathrm{~kg})$ which are similar to this study. Faruque et al. (2010) reported that birth weight of kids of Black Bengal goat were $1.49 \pm 0.13$ and $1.28 \pm 0.11 \mathrm{~kg}$, respectively for intensive and semi intensive rearing system. Paul (2012) reported that average birth weight $(\mathrm{kg})$ of kids of Black Bengal goat in Nucleus Breeding Flock (NBF) at Bangladesh Agricultural University, Modhupur, and Nilphamari were 1.09 \pm 0.27 , $1.09 \pm 0.25$ and $1.10 \pm 0.27 \mathrm{~kg}$, respectively. Jalil (2014) found that birth weight of Black Bengal kid of either sex was $1.31 \pm 0.35 \mathrm{~kg}$.

Table 1. Body weights and body weight gain of male and female goats

\begin{tabular}{lcc|c|c}
\hline \multicolumn{1}{c|}{ Trait } & Male & Female & Total & $\begin{array}{c}\text { Level of } \\
\text { significance }\end{array}$ \\
\hline $\mathrm{N}$ & 100 & 100 & 200 & \\
Birth weight (kg) & $1.08 \pm 0.01$ & $0.98 \pm 0.01$ & $1.03 \pm 0.01$ & $* * *$ \\
Body weight at 6 months (kg) & $8.43 \pm 0.13$ & $7.078 \pm 0.11$ & $7.75 \pm 0.09$ & $* * *$ \\
Body weight at 12months (kg) & $14.28 \pm 0.20$ & $11.27 \pm 0.13$ & $12.77 \pm 0.16$ & $* * *$ \\
Weight gain 0-6 months (g) & $37.71 \pm 0.71$ & $31.05 \pm 0.66$ & $34.38 \pm 0.54$ & $* * *$ \\
Weight gain 6-12 months (g) & $27.41 \pm 0.85$ & $21.83 \pm 0.67$ & $24.62 \pm 0.57$ & $* * *$ \\
\hline
\end{tabular}

$* * * \mathrm{p}<0.001, \mathrm{~N}=$ number of observations

\section{Body weight at different ages}

The average body weights of male and female at 6 and 12 months of age were $8.43 \pm 0.13,14.2 \pm 0.20 \mathrm{~kg}$ and $7.078 \pm 0.11,11.27 \pm 0.13 \mathrm{~kg}$, respectively and average overall body weight of male and female at 6 and 12 months of age were $7.75 \pm 0.09$ and $12.77 \pm 0.16 \mathrm{~kg}$ (Table 2). Effect of sex of goat on the body weight was highly significant $(\mathrm{p}<0.001)$; in all age groups (Table 2). Husain (1993) reported that the body weight of kids at 3, 6, 9 and 12 months of age were $4.9 \pm 0.17,8.4 \pm$ $0.28,10.7 \pm 0.36$ and $12.8 \pm 0.2 \mathrm{~kg}$, respectively in Black Bengal goats which is almost similar with that found in this study. Jalil (2014) reported that live weights at 
$3,6,9$ and 12 month were $5.65,9.63,14.20$ and $17.70 \mathrm{~kg}$, respectively which were also higher than that reported by (Chowdhury et al., 2002 and Hussain et al., 1996) but lower than that reported by Amin (2000). Average body weight of Black Bengal goat was $14.47 \pm 0.48 \mathrm{~kg}$ (Choudhury et al., 2012). Paul (2012) reported that average body weight at 12 months age of Black Bengal goat in NBF, Modhupur, and Nilphamari were $14.40 \pm 0.53,14.20 \pm 0.63$ and $14.30 \pm 0.66 \mathrm{~kg}$ respectively and these regional differences were significant $(\mathrm{p}<0.05)$.

Table 2. Body weights $(\mathrm{kg})$ of goat at 3 different villages

\begin{tabular}{l|c|c|c|c}
\hline \multirow{2}{*}{ Trait } & \multicolumn{3}{|c|}{ Village } & $\begin{array}{c}\text { Level of } \\
\text { significance }\end{array}$ \\
\cline { 2 - 4 } & Kaichapur & Salia & Shimulia & \\
\hline $\mathrm{N}$ & 100 & 100 & 200 & \\
\hline Birth weight $(\mathrm{kg})$ & $1.04 \pm 0.0$ & $1.03 \pm 0.0$ & $1.00 \pm 0.01$ & $\mathrm{NS}$ \\
Body weight at 6 months $(\mathrm{kg})$ & $7.88 \pm 0.1$ & $7.68 \pm 0.1$ & $7.64 \pm 0.1$ & $\mathrm{NS}$ \\
Body weight at 12months $(\mathrm{kg})$ & $13.17 \pm 0.2$ & $12.80 \pm 0.2$ & $12.10 \pm 0.2$ & $*$ \\
\hline
\end{tabular}

$* \mathrm{p}<0.05, \mathrm{NS}=$ Non-Significant $(\mathrm{p}>0.05), \mathrm{N}=$ number of observation

\section{Body weight gain}

The average daily body weight gain of Black Bengal goat at 0-6 and 6-12 months of age were $34.38 \pm 0.54$ and $24.62 \pm 0.57 \mathrm{~g}$, respectively. Effect of sex of goat on the body weight gain was highly significant $(\mathrm{p}<0.001)$; in all regions. The body weight gain of males was higher than female in all regions. Husain et al. (1996) reported that average daily weight gain was $\left(42.7 \pm 0.43 \mathrm{~g} \mathrm{~d}^{-1}\right)$ in the selected group of Black Bengal goats than in the control group $\left(33.3+0.81 \mathrm{~g} \mathrm{~d}^{-1}\right)$ which is nearly similar with the present study. Jalil (2014) reported that body weight gain of Black Bengal goat at 0-3 month, 3-6 month, 6-9 month, and 9-12 month ages were $66.34 \pm 1.69 \mathrm{~g} \mathrm{~d}^{-}$ $1,41.54 \pm 2.02 \mathrm{~g} \mathrm{~d}^{-1}, 49.97 \pm 3.10 \mathrm{~g} \mathrm{~d}^{-1}$ and $39.28 \pm 4.35 \mathrm{~g} \mathrm{~d}^{-1}$, respectively. He also reported that weight gain of Black Bengal goat at $0-12$ month ages was $56.31 \pm 1.40 \mathrm{~g}$ $\mathrm{d}^{-1}$.

\section{Litter size}

The average litter size in Black Bengal does were 1.51 \pm 0.05 . Mia (2011) reported that litter size of doe is 1.50 in NBF; it is also almost similar with the study. Litter size of BBG goat ranged between1 to 3 was reported by Chowdhury and Faruque (2001). Amin (2000) reported litter size of selected BBG goat as 1.96 and those of random population goat as 1.68 , while in Generation $1\left(\mathrm{G}_{1}\right)$ and in Generation $2\left(\mathrm{G}_{2}\right)$ those were 2.15 and 2.18 , respectively. Choudhury et al. (2012) reported that the highest litter size was found in does (1.68 \pm 0.39$)$ of Gangatia village 
(1.67 \pm 0.51$)$ and in Solid color Black Bengal goats (1.67 \pm 0.54$)$. Jalil (2014) reported that litter size of Black Bengal goats was 1.75 \pm 0.03 .

\section{Kid mortality rate}

The average kid mortality rate was found to be $12.58 \%$ in present study, which is close to those reported by Mazumder et al. (1980) and Singh et al. (1991) who reported an average of $13.04 \pm 0.05 \%$ but lower than that reported by Chowdhury et al. (2002). Tsedeke (2007) observed that kid mortality of Arsi Bali goats under traditional system was $12.2 \%$ which is nearly similar with the present study. Choudhury et al. (2012) reported lowest abortion rate was found in Solid Black goats (6.14\%). They also reported the lowest kid mortality was observed in Solid Black goats $(10.0 \%)$ which are lower than the study.

\section{Livelihood through goats}

The observations revealed that the farmers' net change in inventory before and after goat rearing were different. The number of goats of the CBO (Community Based Organization) members increased from 30 percent to 45 percent. The average return from kid was Tk. 2254. The value of kid varied from Tk. 1000-5000. The average net profit from one goat was Tk.754 per annum. So, it was found that with a very small capital, rearing of goat could be an easy way to increase the net income of the farmers. The expenditure in annual food purchase was enhanced by $22.79 \%$. Similarly, increment in the expenditure on clothing, educational status, social dignity, health care status and housing status were $14.22 \%, 4.34 \%, 14.47 \%, 19.35 \%$ and $6.56 \%$ respectively.

\section{Educational and occupational status}

Most of the farmers showed almost the similar record about the literacy status. Most of the farmers are either having Primary level education $(55 \%)$ or illiterate (38.3\%). The selected goat rearers were mostly housewife (95\%), few of them were students (4\%) and teachers (1\%). According to the survey data it was found that most of the goat owner was landless $(75 \%)$ followed by marginal $(6.67 \%)$ and medium $(18.33 \%)$ land holders.

\section{Income status}

The average annual income of the CBO member was Tk. 3556 before the starting project. The highest and lowest income of the CBO member were Tk. 6000 (10\% of total CBO members) and Tk. 2000 (6.60\% of total CBO members). After the project completed, the average income of the CBO member was Tk. 6975. At this stage, the highest and lowest income of the CBO members were Tk. 9750 (30\% of total CBO members) and Tk. 4500 (10\% of total CBO members).

\section{Feeds and feeding management}

The farmers mainly depended on green grasses and tree leaves for feeding their goats. The major sources of feed ingredients they provided to goats were own sources 
which were mainly tree leaves, green grasses and roadside grasses. Hossain et al. (2015) reported that the feed used by $61 \%, 19.5 \%$ and $19.5 \%$ goat farmers were green grass alone, green grass +straw, and green grass + concentrate, respectively. They also found that $65.9 \%$ and $39 \%$ goat farmers supply green grass and concentrate feed respectively to their goats when they keep goats inside the house.

\section{Disease and health care of goats}

There were two major diseases i.e., PPR and skin disease of goat in the study area. It has been observed that the incidence of skin diseases and PPR to be $75 \%$ and $25 \%$, respectively. This indicated that the goats of the experimental area were more susceptible to skin diseases. However, according to Hossain et al. (2015) goats in southern region of Bangladesh were affected by PPR, bloat and anthrax.

\section{Profit from goat rearing}

Average rearing cost per goat in experimental area for 12 months was Tk. 1500. The main return from a goat of experimental area was from kid and yearly income of the farmers from kids of one goat was Tk. 2254. The value varied from Tk. 1077-2254. The net income from one goat in one year was Tk.754.

\section{Livelihood improvement}

The expenditure on food purchase, health care, education status, clothing, housing condition and social status of the goat farmers were increased, respectively at a scale of $22.79 \%, 6.56 \%, 14.47 \%, 4.34 \%, 14.22 \%$ and $19.35 \%$ due to increased income from goat rearing in the study area (Table 3 ). This increased expenditure was possible due to income from the goat rearing alone which might have accrued their better livelihood.

Table 3. Increase of livelihood activities

\begin{tabular}{l|c|c|c|c}
\hline Expenditure in & $\begin{array}{c}\text { Initial value } \\
\text { (TK.) }\end{array}$ & $\begin{array}{c}\text { Final value } \\
\text { (TK.) }\end{array}$ & $\begin{array}{c}\text { Frequency of } \\
\text { added value (\%) }\end{array}$ & $\begin{array}{c}\text { Rank } \\
\text { order }\end{array}$ \\
\hline Food & 1050 & 1360 & 22.79 & 1 \\
Social status & 500 & 620 & 19.35 & 2 \\
Health care & 598 & 640 & 6.56 & 3 \\
Cloths & 440 & 460 & 4.34 & 4 \\
Education & 650 & 760 & 14.47 & 5 \\
House & 350 & 408 & 14.22 & 6 \\
\hline
\end{tabular}




\section{CONCLUSION}

The performance of Black Bengal goats and increased income leading to better livelihood through goat rearing is appreciable. Women employment was dramatically increased because they were involved in their goat rearing. The rural women who were unemployed $(75 \%)$ before and then coming into the job of livestock rearing as their profession was a good sign of the country's development. It is clearly found that the farmers who would rear goats have had rapid changes in their livelihood pattern.

\section{ACKNOWLEDGMENT}

We are grateful to UNEP-GEF-ILRI FAnGR Asia Project for technical support. Special thanks to the Area Development Program Manager (ADPM), World Vision Bangladesh, Phulpur, Mymensingh, for cordial assistance and support.

\section{REFERENCES}

Amin, M. R. 2000. Genetic Improvement of Production Traits in Selective breeding and Crossbreeding. A Ph. D. Thesis. Dept of Anim. Breeding and Genetics, Bangladesh Agriculture University, Mymensingh

Choudhury, M. P., Sarker, S. C., Islam, F., Ali, A., Bhuiyan, A. K. F. H., Ibrahim, M. N. M. and Okeyo, A. M. 2012. Morphometry and performance of Black Bengal goats at the rural community level in Bangladesh. Bangladesh Journal of Animal Science, 41 (2): 83-89

Chowdhury, S. A., Bhuiyan, M. S. A. and Faruque, S. 2002. Rearing Black Bengal goat under semi-intensive management. 1. Physiological and reproductive performances. Asian-Australian Journal of Animal Sciences, 15(4): 477-84

Chowdhury, S. A. and Faruque, S. 2001. Improvement of Black Bengal goat through selective breeding. Research report. Bangladesh Livestock Research Institute, Savar, Dhaka

Faruque, S., Chowdhury, S. A., Siddiquee, N. U. and Afroz, M. A. 2010. Performance and genetic parameters of economically important traits of Black Bengal goat. Journal Bangladesh Agricultural University, 8(1): 67-78

Hossain, M. S., Akhtar, A., Hossain, M. H., Choudhury, M. P. and Islam, F. 2015. Goat husbandry practices in Southern region of Bangladesh. Journal of Bioscience and Agricultural Research, 5 (02): 59-64

Husain, S. S. 1993. A study on the productive performance and genetic potentials of Black Bengal goats, Ph.D thesis. Bangladesh Agricultural University, Mymensingh

Husain, S. S., Horst, P. and Islam, A. B. M. M. 1996. Study on the growth performance of Black Bengal goats in different periods. Small Ruminant Research, 21: 165-171

Jalil, M. A. 2014. Characterization of Black Bengal Goat. A Ph.D. Thesis. Dept of Zoology, Faculty of Biological Sciences, Savar, Dhaka

Mazumder, N. K., Mazumder, A. and Goswami, K. K. 1980. Studies on some factors affecting mortality and survival rates in pashmina kids. Indian Journal of Animal Sciences, 50:281-255 
Mia, M. M. 2011. Genetic evaluation of performance of Black Bengal goat. PhD thesis. Department of Animal breeding and genetics, Bangladesh Agricultural University, Mymensingh

Paul, C. R. 2012. Studies on production and reproduction parameters of Black Bengal Goat. M.S. Thesis, Department of Animal Breeding and Genetics, Bangladesh Agricultural University, Mymensingh

SPSS (2005) Windows for version-14.0. Release on 27.10.2005. (Microsoft Corp.1998). Trends SPSS Inc., Michigan Avenue, Chicago, IL. 19-182

Tsedeke, K. 2007. Production and marketing of sheep and goats in Alaba. Hawassa University, Hawassa, Ethiopia 